\title{
Riffle and pool fish communities in a large stream of southeastern Brazil
}

\author{
Francisco Langeani*, Lilian Casatti*, Helena Seixas Gameiro*, \\ André Bellucco do Carmo**, and Denise de Cerqueira Rossa-Feres*
}

\begin{abstract}
The structure of the fish communities of a pool and a rapid in the ribeirão Santa Bárbara is described. This stream of $5^{\text {th }}$ order is a direct tributary of the rio Tietê in the system of the upper rio Paraná. Thirty three species, from nine families and three orders, were referred in the two mesohabitats: the pool with 31 species, and the rapid with 18. Orders Characiformes, Siluriformes, and Perciformes presented the greatest number of species in the two mesohabitats. The families Characidae and Loricariidae were the most specious, followed by Cichlidae in the pool, and by Parodontidae in the rapid. Most species were accidental, 17 in the pool, and 10 in the rapid, and only six were constant in the two mesohabitats. The greatest diversity and evenness occurred in the pool. The seasonal variation for both assemblages was high, with the pool having a high turnover of species that could be due to the proximity with main channel of the rio Tietê.

A estrutura das comunidades de peixes de um poço e uma corredeira do ribeirão Santa Bárbara é descrita. Esse é um ribeirão de quinta ordem, afluente direto do rio Tietê no sistema do Alto rio Paraná. Trinta e três espécies, de nove famílias e três ordens, foram capturadas nos dois meso-hábitats: 31 no poço e 18 na corredeira. Characiformes, Siluriformes e Perciformes apresentaram o maior número de espécies nos dois meso-hábitats. As famílias Characidae e Loricariidae foram as mais ricas em espécies, seguidas por Cichlidae, no poço, e por Parodontidae, na corredeira. A maioria das espécies foi acidental, 17 no poço e dez na corredeira; somente seis espécies foram constantes nos dois meso-hábitats. As maiores diversidade e uniformidade ocorreram no poço. A variação sazonal no poço e na corredeira foi alta, com o poço apresentando uma grande substituição de espécies, que pode ser devida à proximidade com o canal principal do rio Tietê.
\end{abstract}

Key-words: seasonality, spatial distribution, upper rio Paraná system, niche breadth, diversity, adventitious streams.

\section{Introduction}

The organization of fish assemblages reflects both biotic and abiotic sets of features occurring in a particular moment which influence the distribution, abundance and species interactions, most of them direct or indirect partitioned (Wootton, 1998). Among such resources that can be shared, the habitat often plays an important role in the fish assemblage richness and abundance, because it encompasses several physical structures, such as rocks, logs, leaves, branches, macrophytes, and algae, which are used as food source, shelter, and reproductive or nursery sites for these fishes (Matthews, 1998).

In streams, the structural complexity may be understood as a mosaic of mesohabitat patches (such as pools, runs or raceways, and riffles) which are clearly delimited by different combinations of current, depth, and substrate composition (Angermeier and Schlosser, 1989). Thus, it is predictable that each mesohabitat holds a peculiar ichthyofauna in response to such sets of habitat features. Pools and riffles often support different species composition, which has been observed in temperate (Gorman and Karr, 1978; Gelwick, 1990) and tropical streams (Gorman and Karr, 1978; Angermeier and Karr, 1983; Bührnheim and Cox Fernandes, 2003).

The impressive south-american freshwater fish diversity, estimated in 8,000 species (Schaefer, 1998), is distributed in several aquatic environment types, but mainly in small streams and headwaters. Such environments support small sized species with restrict geographic distribution, high endemism, few or none commercial value and a high dependence from riparian vegetation as source of food, reproduction sites and shelter (Castro and Menezes, 1998). Streams and headwaters have suffered severe human interferences and, because of that, Böhlke et al. (1978) have already alerted about the importance of intensifying collecting efforts in order to assess their diversity before it can be lost. Proportional to their species and

*UNESP, Universidade Estadual Paulista, Departamento de Zoologia e Botânica, Rua Cristóvão Colombo, 2265, 15054-000 São José do Rio Preto, SP, Brazil. e-mail: (FL) langeani@ibilce.unesp.br; (LC) lcasatti@ibilce.unesp.br; (DCRF) denise@ibilce.unesp.br **Rua Dr. Salles Malheiros, 123, 02649-030 São Paulo, SP, Brazil. e-mail: bellucco@usp.br 
habitat diversity, we can say that brazilian streams are environments still scarcely studied and that the few published studies (for example Lemes and Garutti, 2002a, 2002b; Bührnheim and Cox Fernandes, 2003) about the differential use of mesohabitats are not sufficient to clearly define patterns and processes acting on stream assemblages either in pristine or degraded areas. A type of environment even less studied are the adventitious streams, situated between the small headwaters and the rivers. According to Gorman (1986), because of their proximity with the main river, adventitious streams could suffer greater seasonality than streams more distant from main channel. Our objective in developing the present study was to compare diversity, occurrence, habitat use, and seasonal variation between two mesohabitats (pool and riffle) of a relatively large stream tributary of the rio Tietê in southeastern Brazil.

\section{Materials and Methods}

Study site. The ribeirão Santa Bárbara (the term ribeirão is a portuguese word for relatively large streams) is a direct tributary of the rio Tietê right margin, in the Upper rio Paraná system, and is located between the Planalto and Turiúba municipalities, in the northwestern region of the São Paulo State, Brazil. The climate is Aw type and according to Garutti (1988) with a wet season from October to March and a dry season from April to September. In spite of that, in our analysis we have used the volume of rain, and have divided the studied period into high waters, from December to April (total precipitation of $874 \mathrm{~mm}$ ), and low waters, from May to November (total precipitation of $278 \mathrm{~mm}$ ). The studied stretch $\left(20^{\circ} 58^{\prime} 03^{\prime \prime} \mathrm{S} 50^{\circ} 01^{\prime} 6.2^{\prime \prime} \mathrm{W}\right)$ of the ribeirão Santa Bárbara is of fifth order (Strahler, 1957; scale map 1:50,000) and presents a narrow stripe of riparian vegetation. Two mesohabitats, pool and riffle reaches, both isolated by a small fall, were sampled (see physiographical data in Table 1).

Table 1. Physiographical Variables for Each Mesohabitat (pool and riffle) Studied in the Ribeirão Santa Bárbara.

\begin{tabular}{lcc}
\hline Variables & Pool & Riffle \\
\hline Width $(\mathrm{m})$ & 23 & $6.2-13.5$ \\
Length $(\mathrm{m})$ & 49 & 39.5 \\
Mean depth $(\mathrm{m})$ & 0.6 & 0.3 \\
Habitat volume $\left(\mathrm{m}^{3}\right)$ & 557 & 386 \\
Current $(\mathrm{m} / \mathrm{s})$ & 0.4 & 1.1 \\
Bank vegetation & grasses & grasses \\
Bottom type & rock, sand and mud close to the banks & rock \\
\hline
\end{tabular}

Sampling and analyses. Monthly diurnal collections were done from September 1999 to August 2000. The samples were always upriver and started with the pool reach. Effort for each reach was one hour approximately, and included a standardized combination of castnets, sieves, and hand seines, aiming to maximize the sampling and also to make an adequate comparison between the two different mesohabitats. The collected specimens were fixed in formalin $10 \%$, where they remained through 48-72 hours, and the larger specimens were injected with the same solution in the abdominal cavity. Later, they were transferred to a 70\% alcohol solution and deposited in the collection of the Departamento de Zoologia e Botânica, São Paulo State University (UNESP), São José do Rio Preto (DZSJRP 34133430, 3561-3577, 3681-3699, 3712-3737, 3820-3823, 3825, 3828, 3835-3843,3849-3862,3878-3890,3904-3919,3927-3940,3978-3995, 4003-4015, 4046-4057,4310-4337,4737, 5016, 5228, 5265).

The constancy of occurrence of species were calculated for each mesohabitat following Dajoz (1978). Diversity and evenness were compared through Shannon-Wiener and Pielou indices (Odum, 2001). In addition, the species niche breadth for habitat was calculated through the Levin's index (B') (Krebs, 1999). Species with $0 \leq$ B'$^{\prime} \leq 0.3$ had broad niche breadth, those with $0.4 \leq \mathrm{B}^{\prime} \leq 0.7$ showed intermediate breadth, and those with $0.8 \leq \mathrm{B}^{\prime} \leq 1$ showed small breadth. Species abundance model in both mesohabitats were determined with help of the software BioDiversity Pro (McAlecee, unpubl.).

To assess seasonal variation of the assemblages in each mesohabitat, we calculated the coefficient of variation (CV), using relative abundance of the species present in at least $50 \%$ of the collections (Grossman et al., 1990). The CV is calculated by dividing the standard deviation of populations estimated by mean abundance. If $\mathrm{CV} \leq 25 \%$, assemblage is highly constant; $25 \%<\mathrm{CV} \leq 50 \%$, moderately constant; $50 \%<\mathrm{CV} \leq 75 \%$, moderately variable; $\mathrm{CV} \geq 76 \%$, highly variable (Grossman et al., 1990). We quantified the differences in the abundance and the composition of the ichthyofauna for both mesohabitats along the study period using non-metric multidimensional scaling analysis (MDS), a method for bidimensional arrangement which represents the association among samples in a similarity matrix; this analysis have been considered a robust technique for analyzing ecological data (Minchin, 1987). To quantify the similarity among months we used the Bray-Curtis distance measure applied to $\log (\mathrm{x}+1)$ transformed data, in multivariate analyses software PRIMER 5 (Clarke and Gorley, 2001).

\section{Results}

In the ribeirão Santa Bárbara we have registered 33 fish species (Table 2), in nine families and three orders. The pool encompassed 31 species in nine families and three orders, whereas the riffle included 18 species in eight families and three orders (Table 2). In the pool, $61 \%$ of species belonged to the Order Characiformes, $26 \%$ to Siluriformes, and 13\% to Perciformes; in the riffle $61 \%$ belonged to Characiformes, $28 \%$ to Siluriformes, and $11 \%$ to Perciformes. The highest richness were found in Characidae, Loricariidae, and Cichlidae (pool), and in Characidae, Loricariidae, and Parodontidae (riffle).

The majority of fish species presented accidental occurrence (Table 2) both in the riffle ( $\mathrm{n}=10,56 \%$ ), and in the pool reach $(\mathrm{n}=17,55 \%)$. Only six species were constant in both mesohabitats (Astyanax altiparanae, A. fasciatus, Bryconamericus turiuba, B. stramineus, Hypostomus hermani, and $H$. variipictus). 


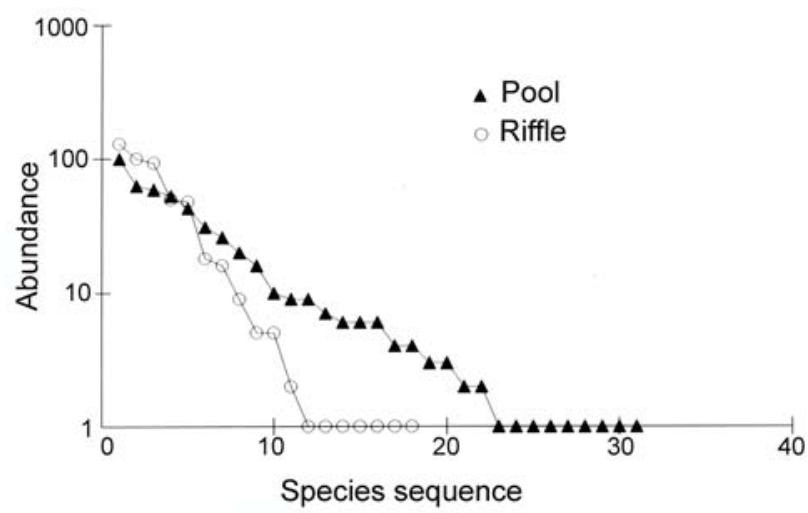

Fig. 1. Model of species abundance for each mesohabitat studied in the ribeirão Santa Bárbara, southeastern Brazil.

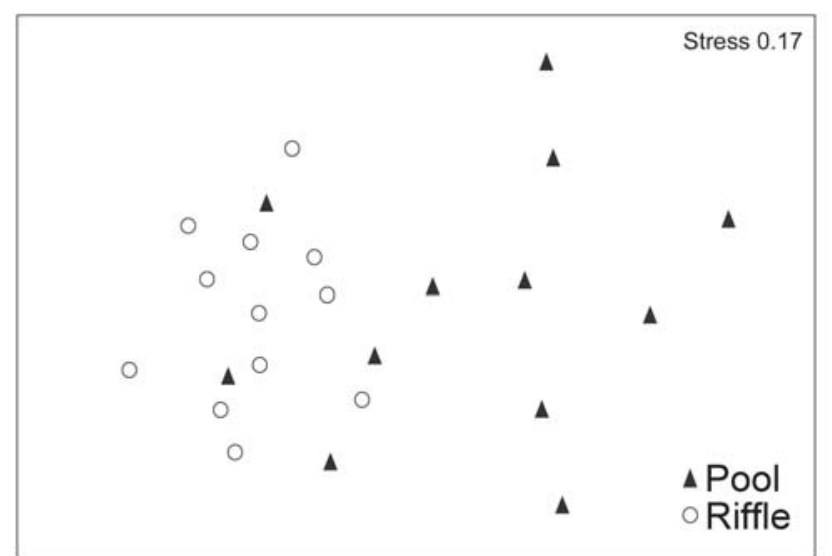

Fig. 2. Multidimensional scaling plot based on species abundance data in the riffle and pool reaches. Each symbol represents a month.

In the pool reach the species diversity and evenness were higher $\left(\mathrm{H}^{\prime}=1.15, \mathrm{e}=0.77\right)$ than in the riffle reach $\left(\mathrm{H}^{\prime}=0.86\right.$, e $=0.68)$. Both pool and riffle samples showed a log series model of species abundance (Fig. 1). Non-metric multidimensional analysis showed spatial segregation according to the mesohabitats (Fig. 2), with Astyanax fasciatus, Bryconamericus stramineus, Apareiodon piracicabae, Parodon nasus, Pimelodella avanhandavae, Hypostomus hermani, and Crenicichla jaguarensis showing great niche breadth for habitat (Table 3). Five species showed intermediate niche breadth, with Astyanax altiparanae, Serrapinnus heterodon, and Imparfinis schubarti occurring mostly in the pool, and Bryconamericus turiuba, and Hypostomus variipictus, mostly in the riffle. Remaining species $(n=21)$ showed small niche breadth, indicating specialization in one or other mesohabitat.

Within each mesohabitat, assemblage structure was remarkably influenced by water level (Fig. 3). In the pool reach Steindachnerina insculpta was very abundant in low as well as in high-water period, and many other species had intermediate abundance (Table 3). In the riffle reach Hypostomus variipictus, Hypostomus hermani, Bryconamericus turiuba were dominant, and among those $H$. hermani was clearly more related to high-waters (Fig. 4; Table 3).

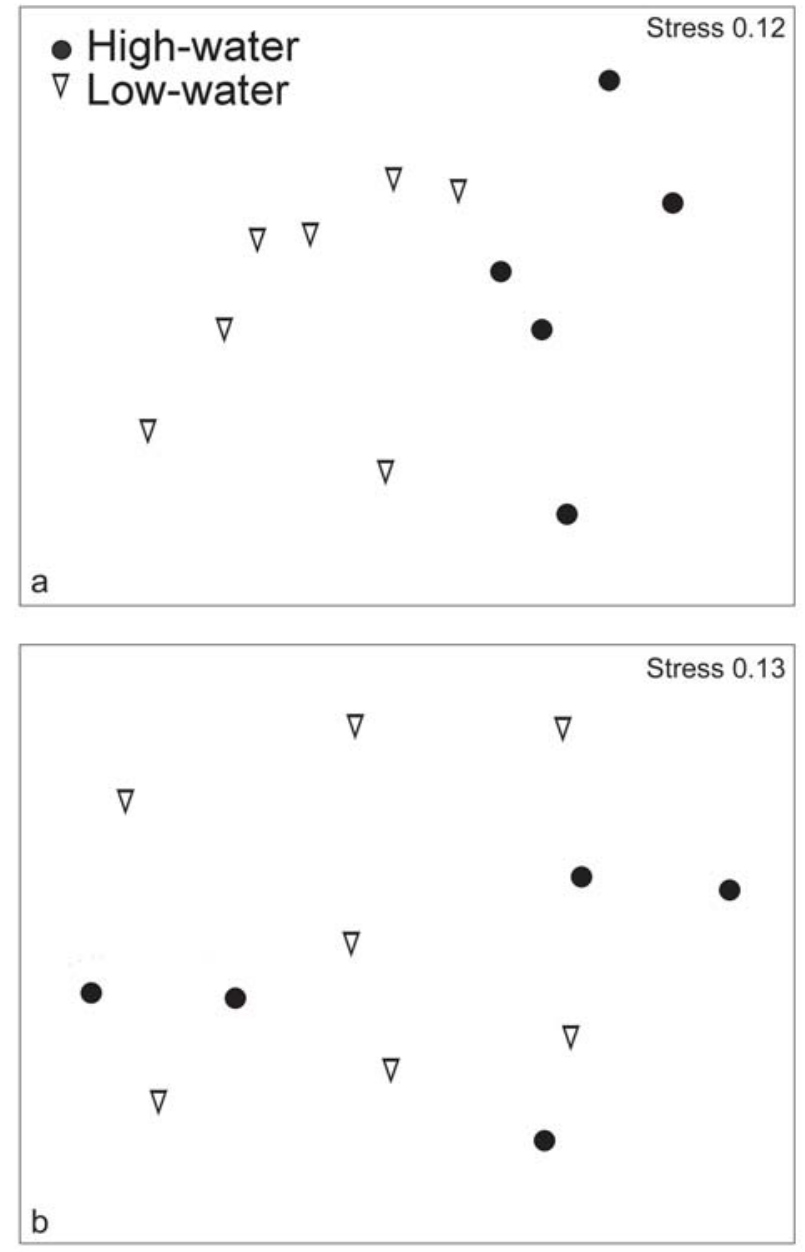

Fig. 3. Multidimensional scaling plot based on species abundance data in the riffle (a) and pool reaches (b) according to low and high-waters level. Each symbol represents a month.

The riffle samples also were more closely in the ordination space than the pool samples (Fig. 2), showing a smaller variation in the ichthyofauna structure. In this mesohabitat the CV value was $91 \%$, whereas in the pool CV was $124 \%$.

\section{Discussion}

The high values for richness and abundance presented by Characiformes and Siluriformes are in accordance to the general pattern of taxonomic composition for south american rivers and streams (Lowe-McConnell, 1987). Similarly, the predominance of Characidae is also documented in other streams of the Upper rio Paraná system, followed by Loricariidae and Heptapteridae (Castro et al., 2003) or Loricariidae and Cichlidae (Castro et al., 2004). In the Santa Bárbara riffle, Characidae was followed by Loricariidae and Parodontidae, which are specialized in scraping periphyton from rocks, and whose species were particularly associated to high-water period. In the pool, Characidae and Loricariidae were followed by Cichlidae, a group with species adapted to slow-waters.

Among the 33 registered species, Cichla monoculus, Tilapia sp., Satanoperca pappaterra, and Metynnis maculatus 
are non-native; the first is from Amazonas River basin (Kullander, 2003), the second is from Africa (Eschmeyer, 1998), and both were introduced in the Upper Paraná with economic and sport fishing purposes. The last two species are respectively from Amazonas and Paraguay basins (Kullander, 2003; Jégu, 2003), and have became very common in the reservoirs of the Upper Paraná after the construction of Itaipu dam, whose waters covered the Salto de Sete Quedas, a natural physical barrier between Upper Paraná and remaining portion of the Paraná-Paraguay system. Despite having a low abundance in the studied stream, all non-native species show a relative dispersion success because they have been registered also in many other streams of the Upper Paraná (Pavanelli and Caramaschi, 1997; Castro et al., 2003; Castro et al., 2004).

The constancy of occurrence, a qualitative measure (Dajoz, 1978), shows which species are resident or migrant in a particular assemblage. Commonly, the most constant species were also those with greater abundance, what is clearly seen in the Santa Bárbara stream for Astyanax altiparanae, $A$. fasciatus, Bryconamericus stramineus, B. turiuba,
Hypostomus hermani, and H. variipictus, all constant and the most abundant species in both stretches. This pattern was also registered in other streams of the Upper Paraná (Uieda, 1984) and of the Atlantic rainforest (Sabino and Castro, 1990).

The studied mesohabitats, however, show a predominance of accidental species, also evidencied through the analysis of the species abundance model obtained. In the log series model the small number of abundant species and the large proportion of rare species suggest situations where one or a few factors dominate the ecology of a community (Magurran, 1988). At this moment, we are not able to identify the factors dominating the fish assemblage structure in the ribeirão Santa Bárbara, but its proximity with the main channel of the rio Tietê could explain the higher number of rare species (e. g. Moenkhausia intermedia, Metynnis maculatus, Serrasalmus spilopleura, Aphyocharax dentatus, Leporinus lacustris, Cichla monoculus, Crenicichla lacustris, C. jaguarensis, and Satanoperca pappaterra), typically found in larger body waters, which could be temporarily exploring the studied

Table 2. Fish Species Collected in the Ribeirão Santa Bárbara Mesohabitats with Total Number of Specimens (N) and Occurrence (Oc, in Percentage). Low and High Refer Respectively to Low and High Waters.

\begin{tabular}{|c|c|c|c|c|c|c|c|}
\hline \multirow[t]{2}{*}{ Order and family } & \multirow[t]{3}{*}{ Species } & \multicolumn{3}{|c|}{ Pool } & \multicolumn{3}{|c|}{ Riffle } \\
\hline & & \multicolumn{2}{|c|}{$\mathrm{N}$} & \multicolumn{4}{|c|}{$\mathrm{N}$} \\
\hline & & low & high & Oc & low & high & Oc \\
\hline \multicolumn{8}{|l|}{ CHARACIFORMES } \\
\hline \multirow[t]{10}{*}{ Characidae } & Astyanax altiparanae & 38 & $\begin{array}{c}21 \\
6\end{array}$ & 91.7 & 10 & $\begin{array}{c}8 \\
19\end{array}$ & $\begin{array}{l}66.7 \\
91.7\end{array}$ \\
\hline & $\begin{array}{l}\text { Astyanax fasciatus } \\
\text { Bryconamericus stramineus }\end{array}$ & $\begin{array}{l}20 \\
39\end{array}$ & $\begin{array}{c}6 \\
14\end{array}$ & $\begin{array}{l}75.0 \\
58.3\end{array}$ & $\begin{array}{l}29 \\
48\end{array}$ & $\begin{array}{c}19 \\
2\end{array}$ & $\begin{array}{l}91.7 \\
75\end{array}$ \\
\hline & $\begin{array}{l}\text { Bryconamericus stramineus } \\
\text { Bryconamericus turiuba }\end{array}$ & 25 & 6 & $\begin{array}{l}58.3 \\
66.7\end{array}$ & $\begin{array}{l}48 \\
46\end{array}$ & $\begin{array}{c}2 \\
54\end{array}$ & 100 \\
\hline & Moenkhausia intermedia & 0 & 1 & 8.3 & - & - & - \\
\hline & Moenkhausia sanctaefilomenae & 0 & 1 & 8.3 & - & - & - \\
\hline & Metynnis maculatus & 0 & 9 & 16.7 & - & - & - \\
\hline & Serrasalmus spilopleura & 1 & 1 & 16.7 & - & - & - \\
\hline & Aphyocharax dentatus & 0 & 1 & 8.3 & - & - & - \\
\hline & Serrapinnus heterodon & 3 & 0 & 16.7 & 0 & 1 & 8.3 \\
\hline & Serrapinnus notomelas & 16 & 0 & 33.3 & - & - & - \\
\hline Crenuchidae & Characidium zebra & 5 & 1 & 41.7 & 1 & 0 & 8.3 \\
\hline \multirow[t]{2}{*}{ Curimatidae } & Steindachnerina insculpta & 66 & 34 & 66.7 & 3 & 2 & 25.0 \\
\hline & Cyphocharax modestus & 4 & 0 & 25.0 & - & - & - \\
\hline \multirow[t]{3}{*}{ Anostomidae } & Leporinus friderici & 17 & 3 & 58.3 & 0 & 1 & 8.3 \\
\hline & Leporinus lacustris & 1 & 0 & 8.3 & - & - & - \\
\hline & Leporinus striatus & 9 & 0 & 33.3 & - & - & - \\
\hline \multirow[t]{3}{*}{ Parodontidae } & Apareiodon ibitiensis & - & - & - & 0 & 16 & 41.7 \\
\hline & Apareiodon piracicabae & 3 & 3 & 41.7 & 2 & 7 & 25.0 \\
\hline & Parodon nasus & 4 & 0 & 25.0 & 1 & 4 & 33.3 \\
\hline \multirow{4}{*}{ Heptapteridae } & & & & & & & \\
\hline & Imparfinis schubarti & 5 & 1 & 41.7 & 1 & 1 & 16.7 \\
\hline & Rhamdia quelen & 1 & 0 & 8.3 & - & - & - \\
\hline & Pimelodella avanhandavae & 1 & 0 & 8.3 & 1 & 0 & 8.3 \\
\hline Callichthyidae & Aspidoras fuscoguttatus & 2 & 1 & 25.0 & - & - & - \\
\hline \multirow[t]{4}{*}{ Loricariidae } & Hypostomus hermani & 50 & 13 & 75.0 & 19 & 74 & 100 \\
\hline & Hypostomus variipictus & 21 & 18 & 83.0 & 51 & 78 & 100 \\
\hline & Hypostomus regani & 7 & 7 & 42.0 & - & - & - \\
\hline & Rineloricaria latirostris & 5 & 5 & 50.0 & 0 & 1 & 8.3 \\
\hline \multicolumn{8}{|l|}{ PERCIFORMES } \\
\hline \multirow[t]{5}{*}{ Cichlidae } & Cichla monoculus & 0 & 1 & 8.3 & - & - & - \\
\hline & Crenicichla lacustris & 1 & 1 & 16.7 & - & - & - \\
\hline & Crenicichla jaguarensis & 1 & 0 & 8.3 & 1 & 0 & 8.3 \\
\hline & Satanoperca pappaterra & 0 & 1 & 8.3 & - & - & - \\
\hline & Tilapia sp. & - & - & - & 0 & 1 & 8.3 \\
\hline
\end{tabular}




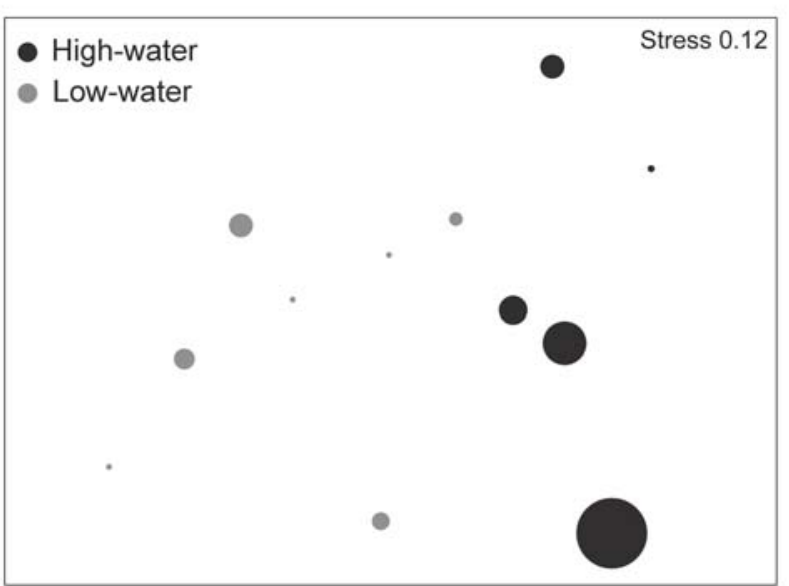

Fig. 4. Multidimensional scaling plot of Hypostomus hermani abundance in the riffle reach showing its predominance (shown by circle size) during the high-waters. Each symbol represents a month.

reaches for feeding or reproduction.

The higher species diversity found in the pool reach, when compared to the riffle reach, can be explained as a result of the habitat complexity and/or habitat volume, as already documented for other temperate and tropical streams (Gorman and Karr, 1978). In our study the accentuated complexity in the pool reach was probably related to the submerged vegetation and substrate combinations. Furthermore, higher habitat volume appears to be associated to higher habitat complexity and food resources, which support more niches and more species (Williams, 1964). Thereby, we hypothesized that habitat volume, associated with habitat complexity, may be a meaningful descriptor in predicting species richness for large streams. Similar findings were registered in seven streams studied in the Central and North America, where not only the habitat volume but also the historical factors affecting the number of available species for colonization - facilitating or inhibiting migrant species - must be responsible for the number of species in a particular site (Angermeier and Schlosser, 1989).

In streams the mesohabitats, which can be seen as habitat patches for fishes, can be easily characterized by peculiar combinations of depth, substrate, and current. Because these patches are generally too small to support self-sustaining fish populations, and without physicochemical barriers to prevent fish movement between them, it is possible that predation pressures play an important role in structuring fish stream communities (Angermeier and Schlosser, 1989). The use of resources in a brazilian coastal stream showed correlation between the predator Hoplias malabaricus with Poecilia vivipara densities (Mazzoni and Iglesias-Rios, 2002). In the ribeirão Santa Bárbara we did not test predation pressures, but predominantly or partially piscivorous fish species (Cichla monoculus, Rhamdia quelen, Serrasalmus spilopleura, Crenicichla lacustris, and C.jaguarensis) were few and rare, with their occurrence related to the high-waters.

The role of the seasonality structuring tropical fish communities is well known (Lowe-McConnell, 1987). Particular species may be only registered during specific periods of the year, and/or in specific mesohabitats, when hydraulic conditions are favorable to them. In the ribeirão Santa Bárbara, the majority of species with broad seasonal occurrence were those constant and registered in both mesohabitats, revealing few or none influence of seasonality. Some rare species however occurred only during high-waters, what presumably facilitated their upriver migration: Moenkhausia intermedia, Metynnis maculatus, Aphyocharax dentatus, Cichla monoculus, and Satanoperca pappaterra.

In lotic systems, natural seasonal variations in flow regimes can produce substantial fluctuations in the physical

Table 3. Niche Breadth (B') for Habitat Use of the Fishes Registered in the Ribeirão Santa Bárbara Mesohabitats.

\begin{tabular}{|c|c|c|}
\hline Broad $0 \leq \mathrm{B}^{\prime} \leq 0.3$ & Intermediate $0.4 \leq \mathrm{B}^{\prime} \leq 0.7$ & Small $0.8 \leq \mathrm{B}^{\prime} \leq 1$ \\
\hline Apareiodon piracicabae & Astyanax altiparanae & Apareiodon ibitiensis \\
\hline Astyanax fasciatus & Bryconamericus turiuba & Aphyocharax dentatus \\
\hline Bryconamericus stramineus & Hypostomus variipictus & Aspidoras fuscoguttatus \\
\hline Crenicichla jaguarensis & Imparfinis schubarti & Characidium zebra \\
\hline Hypostomus hermani & Serrapinnus heterodon & Cichla monoculus \\
\hline Parodon nasus & & Crenicichla lacustris \\
\hline \multirow[t]{15}{*}{ Pimelodella avanhandavae } & & Cyphocharax modestus \\
\hline & & Hypostomus regani \\
\hline & & Leporinus friderici \\
\hline & & Leporinus lacustris \\
\hline & & Leporinus striatus \\
\hline & & Metynnis maculatus \\
\hline & & Moenkhausia intermedia \\
\hline & & Moenkhausia sanctaefilomenae \\
\hline & & Rhamdia quelen \\
\hline & & Rineloricaria latirostris \\
\hline & & Satanoperca pappaterra \\
\hline & & Serrapinnus notomelas \\
\hline & & Serrasalmus spilopleura \\
\hline & & Steindachnerina insculpta \\
\hline & & Tilapia $\mathrm{sp}$. \\
\hline
\end{tabular}


environment and, thus, in the species abundance. A hypothesized consequence of this variation is the prevention of competitive exclusion through its negative effect on population size (Grossman et al., 1990). Some authors suggest that some populations of stream fish assemblages could vary substantially (Grossman et al., 1990), whereas others show stability and persistence (Matthews, 1986; Matthews et al., 1988; Meffe and Berra, 1988), and these discrepancies have caused some ecological debate (Grossman et al., 1982; Yant et al., 1984). In brazilian streams, Mazzoni and Lobón-Cerviá (2000) observed some spatio-temporal persistence of the ichthyofauna in an isolated coastal stream, without lateral and longitudinal migration neither periodical pulsed floods.

Streams reaches located in natural areas seem to show a tendency to stability, with pools being often stable across months or weeks (Meffe and Berra, 1988). In the ribeirão Santa Bárbara, however, we have observed a highly fluctuating community that, despite presenting a riparian vegetation, its drainage is included in a very impacted geographical region, where pasture and agriculture dominate the land use, what could partially explain this high variation. When comparing riffles and pools, the last are often more stable across months or weeks (Meffe and Berra, 1988), but their assemblages could be rapidly altered by floods, movements or predators (Matthews, 1998), and for these reasons, when compared with riffles their fish assemblages could be more variable. The ichthyocenosis structure from the Ribeirão Santa Bárbara pool was more variable than that from the riffle, specially during the high waters period when most accidental and rare species occurred.

Furthermore, it is important to note that the studied ichthyofauna does not fit in the current definition proposed by Castro (1999), in which stream fishes are represented by smallsize species, often absent in larger water courses. The species registered in the ribeirão Santa Bárbara are not restricted to small streams, and most of them are also found in larger environments such as rivers and reservoirs.

Finally, the high number of rare species specially associated to the high-waters season and the high variation in the structure of the ichthyofauna might be a consequence of the proximity to the rio Tietê, probably representing a natural pattern to be expected in this type of environment, which should be considered a transition between headwaters and rivers. Future works in other similar environments should corroborate the pattern observed here and the researchers should also be aware about the importance to standardize the sample efforts in order to manage adequately this highly seasonal kind of environment.

\section{Acknowledgements}

We thank G. Q. Cordeiro, H. F. Chaves, K. J. Contiero, and undergraduate students from the Special Training Program for Biological Sciences (PET Ciências Biológicas) for their help in the field work. R. S. C. Ferreira and V. X. L. Andrade assisted the curatorial work. R. L. Moura helped us with sta- tistical analysis. R. Mazzoni and two anonymous reviewers made valuable suggestions to improve the text. This work was partly supported by grants from the Fundação de Amparo à Pesquisa do Estado de São Paulo to FL (99/05193-2), DCRF (01/07944-7), and LC (01/13340-7), and by grants from the Conselho Nacional de Pesquisas Científicas to FL (300474/ 1999-7).

\section{Literature Cited}

Angermeier, P. L. \& J. R. Karr. 1983. Fish communities along environmental gradients in a system of tropical streams. Environmental Biology of Fishes, 9:117-135.

Angermeier, P. L. \& I. J. Schlosser. 1989. Species-area relationships for stream fishes. Ecology, 70:1450-1642.

Böhlke, J., S. H. Weitzman \& N. A. Menezes. 1978. Estado atual da sistemática de peixes de água doce da América do Sul. Acta Amazonica, 8:657-677.

Bührnheim, C. M. \& C. Cox-Fernandes. 2003. Structure of fish assemblages in Amazonian rain-forest streams: effects of habitats and locality. Copeia, 2003:255-262.

Castro, R. M. C. 1999. Evolução da ictiofauna de riachos sulamericanos: padrões gerais e possíveis processos causais. Pp. 139-155. In: Caramaschi, E.P.; R. Mazzoni \& P. R. PeresNeto (Eds.). Ecologia de peixes de riachos. Série Oecologia Brasiliensis, Rio de Janeiro, 260p.

Castro, R. M. C. \& N. A. Menezes. 1998. Estudo diagnóstico da diversidade de peixes do estado de São Paulo. Pp. 113. In: R. M. C. Castro (Ed.). Biodiversidade do Estado de São Paulo: Vertebrados. FAPESP, São Paulo, 71p.

Castro, R. M. C., L. Casatti, H. F. Santos, K. M. Ferreira, A. C. Ribeiro, R. C. Benine, G. Z. P. Dardis A. L. A. Melo, R. Stopiglia, T. X. Abreu, F. A. Bockmann, M. Carvalho, F. Z. Gibran, \& F. C. T. Lima. 2003. Estrutura e composição da ictiofauna de riachos do rio Paranapanema, sudeste do Brasil. Biota Neotropica, 3: http:// www.biotaneotropica.org.br/v3n1/pt/abstract? article+BN01703012003.

Castro, R. M. C., L. Casatti, H. F. Santos, A. L. A. Melo, L. S. F. Martins, K. M. Ferreira, F. Z. Gibran, R. C. Benine, M. Carvalho, A. C. Ribeiro, T. X. Abreu, F. A. Bockmann, G. Z. P. Dardis, R. Stopiglia \& F. Langeani. 2004. Estrutura e composição da ictiofauna de riachos da bacia do rio Grande no estado de São Paulo, sudeste do Brasil. Biota Neotropica, 4: http://www.biotaneotropica.org.br/v4n1/pt/ abstract?article+BN01704012004.

Clarke, K. R. \& R. N. Gorley. 2001. PRIMER v5: User manual/ tutorial. PRIMER-E, Plymouth, 91p.

Dajoz, R. 1978. Ecologia geral. Editora Vozes and EDUSP, São Paulo, 472p.

Eschmeyer, W. N. (Ed.) 1998. Catalog of fishes. California Academy of Sciences, San Francisco, 2905p.

Garutti, V. 1988. Distribuição longitudinal da ictiofauna de um córrego na região noroeste do estado de São Paulo, Bacia do rio Paraná. Revista Brasileira de Biologia, 48:747-759.

Gelwick, F. P. 1990. Longitudinal and temporal comparisons 
of riffle and pool fish assemblages in a Northeastern Oklahoma Ozark stream. Copeia, 1990:1072-1082.

Gorman, O. T. 1986. Assemblage organization of stream fishes: the effect of rivers on adventitious streams. American Naturalist, 128:611-616.

Gorman, O. T. \& J. R. Karr. 1978. Habitat structure and stream fish communities. Ecology, 59:507-515.

Grossman, G. V., J. F. Dowd \& M. Crawford. 1990. Assemblage stability in stream fishes: a review. Environment Management, 14:661-671.

Grossman, G. V., P. B. Moyle \& J. O. Whitaker. 1982. Stochasticity in structural and functional characteristics of an Indiana stream fish assemblage: a test of community theory. American Naturalist, 120:423-454.

Jégu, M. 2003. Serrasalminae. Pp. 182-196. In: Reis, R.E.; S. O. Kullander \& C. J. Ferraris Jr. (Orgs.). Check list of the freshwater fishes of South and Central America. EDIPUCRS, Porto Alegre, Brazil, 729p.

Krebs, C. J. 1999. Ecological methodology. Addison Wesley Longman, New York, 620p.

Kullander, S. O. 2003. Family Cichlidae (Cichlids). Pp. 605654. In: Reis, R.E.; S. O. Kullander \& C. J. Ferraris Jr. (Orgs.). Check list of the freshwater fishes of South and Central America. EDIPUCRS, Porto Alegre, 729p.

Lemes, E. M. \&V. Garutti. 2002a. Ecologia da ictiofauna de um córrego de cabeceira da bacia do Alto rio Paraná, Brasil. Iheringia, 92:69-78.

Lemes, E. M. \&V. Garutti. 2002b. Ictiofauna de poção e rápido em um córrego de cabeceira da bacia do Alto rio Paraná. Comunicações do Museu de Ciências e Tecnologia, PUCRS, Sér. Zool., 15:175-199.

Lowe-McConnell, R. H. 1987. Ecological studies in tropical fish communities. Cambridge University Press, Cambridge, $382 \mathrm{p}$.

Magurran, A. E. 1988. Ecological diversity and its measurement. Chapman and Hall, London, 178p.

Matthews, W. J. 1986. Fish faunal structure in an Ozark stream: stability persistence and a catastrophic flood. Copeia, 1986:388-397.

Matthews, W. J. 1998. Patterns in freshwater fish ecology. Chapman and Hall, New York, USA, 756p.

Matthews, W. J, R. C. Cashner \& F. P. Gelwick. 1988. Stability and persistence of fish faunas and assemblages in three midwestern streams. Copeia, 1988:945-955.

Mazzoni, R. \& J. Lobón-Cerviá. 2000. Longitudinal structure, density and production rates of a neotropical stream fish assemblage: the river Ubatiba in the Serra do Mar, south- east Brazil. Ecography, 23:588-602.

Mazzoni, R. \& R. Iglesias-Rios. 2002. Distribution patterns of two species in a coastal stream in southeast Brazil. Brazilian Journal of Biology, 62:171-178.

Meffe, G. K. \& T. M. Berra. 1988. Temporal characteristics of fish assemblage structure in an Ohio stream. Copeia, 1988:684-690.

Minchin, P. R. 1987. An evaluation of the relative robustness of techniques for ecological ordination. Vegetatio, 69:89107.

Odum, E. P. 2001. Fundamentos de ecologia. Fundação Calouste Gulbenkian, Lisboa, 927p.

Pavanelli, C. S. \& E. P. Caramaschi. 1997. Composition of the ichthyofauna of two small tributaries of the Paraná river, Porto Rico, Paraná State, Brazil. Ichthyological Exploration of Freshwaters, 8:23-31.

Sabino, J. \& R. M. C. Castro. 1990. Alimentação, período de atividade e distribuição espacial dos peixes de um riacho da floresta Atlântica (Sudeste do Brasil). Revista Brasileira de Biologia, 50:23-36.

Schaefer, S. A. 1998. Conflict and resolution: impact of new taxa on phylogenetic studies of neotropical cascudinhos (Siluroidei: Loricariidae). Pp. 375-400. In: Malabarba, L.R.; R. E. Reis, R. P. Vari, Z. M. S. Lucena \& C. A. S. Lucena (Eds.). Phylogeny and classification of neotropical fishes. EDIPUCRS, Porto Alegre, 603p.

Strahler, A. N. 1957. Quantitative analysis of watershed geomorphology. Transactions of the American Geophysical Union, 38:913-920.

Uieda, V. S. 1984. Ocorrência e distribuição dos peixes em um riacho de água doce. Revista Brasileira de Biologia, 44:203213.

Williams, C. B. 1964. Patterns in the balance of the nature and related problems in quantitative ecology. Academic Press, New York, 324p.

Wootton, R. J. 1998. Ecology of teleost fishes. Kluwer Academic Publishers, London, 385p.

Yant, P.R., J. R. Karr \& P. L. Angermeier. 1984. Stochasticity in stream fish communities: an alternative interpretation. American Naturalist, 124:573-582.
Received February 2005 Accepted June 2005 